\title{
Karakter Genetik Populasi Bedeng 61B Desa Wonokarto Kabupaten Lampung Timur Pasca Program Kolonisasi Pemerintah Belanda
}

\author{
YUSTIN NUR KHOIRIYAH \\ Politeknik Kesehatan Kementerian Kesehatan Tanjungkarang \\ Jl. Soekarno Hatta No. 6 Hajimena Bandar Lampung \\ email: yustin_nurkhoiriyah@yahoo.co.id
}

\begin{abstract}
Gene and genotype frequencies are important in a population characterizing. Based on the frequency of these gene and genotype, distinctiveness of population can be determined (Arisuryanti et al., 2007). Gene frequencies of population can be changed if there are evolutionary forces (the factors that play a role in changing the allele and genotype frequencies), such as, mutation, migration, non-random mating, genetic drift and natural selection (Arisuryanti \& Daryono, 2007). Migration and genetic drift were thought to be a factor that changed alleles and genotype frequencies in the population of Lampung. Witrianto (2010) showed migration programs that were triggered by the Dutch government, it was called colonization. Therefore, in the population of Lampung, indication of changes in allele and genotype frequencies were need to be evaluated.

The results showed that frequency of alleles $\mathrm{I}^{\mathrm{A}}, \mathrm{I}^{\mathrm{B}}$ and $\mathrm{I}^{\mathrm{O}}$ in the population were $0.17 ; 0.21$ and 0.62, respectively. Frequency of genotype $\mathrm{I}^{\mathrm{A}} \mathrm{I}^{\mathrm{A}}, \mathrm{I}^{\mathrm{A}} \mathrm{I}^{\mathrm{O}}, \mathrm{I}^{\mathrm{B}} \mathrm{I}^{\mathrm{B}}, \mathrm{I}^{\mathrm{B}} \mathrm{I}^{\mathrm{O}}, \mathrm{I}^{\mathrm{A}} \mathrm{I}^{\mathrm{B}}$ and $\mathrm{I}^{\mathrm{O}} \mathrm{I}^{\mathrm{O}}$ were $0.290 ; 0.2108$; $0.0441 ; 0.2604 ; 0.0650$ and 0.3800 , respectively. Chi Square test showed that the value of $\mathrm{X}^{2}$ were $0,07\left(\mathrm{X}^{2}<\alpha\right.$ critical value at $5 \%$ for $\left.\mathrm{dF}=3\right)$. It can be concluded that alleles and genotype distribution of $\mathrm{ABO}$ blood system in the population were in accordance with Hardy-Weinberg equilibrium law, so that the equilibrium legal status were applied in this population. Genetic drift and gene flow were not affected alleles and genotype changes. The process of microevolution were not occur in the population of people from the $61 \mathrm{~B}$ plot of Wonokarto village.
\end{abstract}

Keywords: character of genetic population, post-colonization of Dutch government, the 61 B plot of Wonokarto village

\section{PENDAHULUAN}

Genetika populasi adalah salah satu cabang ilmu genetika yang mempelajari variasi genetik dalam suatu populasi. Cabang ilmu genetika ini banyak diaplikasikan dalam berbagai bidang, khususnya kesehatan, pemuliaan, dan konservasi. Genetika populasi mengenali arti penting dari sifat kuantitatif, karena cara menentukan penyebaran alel tersebut dilakukan secara matematis. Salah satu saja frekuensi dari suatu gen diketahui dapat digunakan untuk memprediksi frekuensi gen yang lain. Hal tersebut dapat diaplikasikan dalam mendiagnosa penyakit genetik (Arisuryanti \& Daryono, 2007; Campbell dkk., 2003; Sofro, 1994).

Frekuensi gen pada suatu populasi dapat berubah apabila terdapat evolutionary forces, yaitu faktor-faktor yang berperan dalam mengubah frekuensi alel dan genotip, antara lain mutasi, migrasi, perkawinan tidak acak, genetic drift dan seleksi alam (Arisuryanti \& Daryono, 2007). Migrasi dan genetic drift diduga menjadi faktor yang mengubah frekuensi alel dan genotip pada populasi Lampung. Witrianto (2010) menunjukkan adanya program migrasi yang dicetus oleh pemerintah Hindia Belanda yang disebut kolonisasi. Program ini dimulai pertama kali pada bulan November 1905, sejumlah 155 KK (815 jiwa) yang berasal dari Jawa Tengah dipindahkan ke Lampung. Dalam periode 1905-1942, penduduk yang berhasil dipindahkan sebanyak 235.802 orang penduduk. Daerah asal terbanyak ialah Jawa Timur 27.044 KK (90.086 jiwa) dan yang terkecil D.I. Yogyakarta $188 \mathrm{KK}$ (750 jiwa). Daerah tujuan terbanyak ialah Lampung 44.687 KK (175.867 jiwa) dan yang terkecil Sulawesi Selatan 137 KK (457 jiwa). Setelah 
Indonesia merdeka, program pemindahan penduduk yang kemudian disebut transmigrasi, dimulai kembali. Pada tanggal 12 Desember 1950, diberangkatkan 23 KK (77 jiwa) dari Provinsi Jawa Tengah menuju Lampung.

Kecamatan Sekampung merupakan salah satu tujuan program transmigrasi kolonial Belanda tahun 1930an. Kecamatan Sekampung saat ini terdiri dari 17 desa, salah satunya adalah Desa Wonokarto. Desa ini sering juga disebut dengan Bedeng 61/ distrik 61 , yang terbagi menjadi 4 (empat) antara lain bedeng 61, 61A, 61B, dan 61C. Awalnya desa ini masuk dalam wilayah Lampung Tengah yang terdiri dari 67 bedeng/ distrik. Saat ini, desa Wonokarto masuk dalam wilayah Lampung Timur akibat adanya pemekaran (Setiawan, 2009). Selain terdapat indikasi adanya evolutionary forces, bedeng 61B memiliki batasan wilayah yang jelas, wilayah ini terpisah dari kawasan lainnya yang dapat memperkecil terjadinya aliran gen dari populasi lain. Batasan wilayah yang jelas akan memperjelas batasan populasi.

Perpindahan individu atau sekelompok individu ke dalam sebuah populasi akan menyebabkan terjadinya aliran gen (gene flow) dari suatu populasi ke populasi lainnya. Dampak aliran gen adalah frekuensi alel dan genotip populasi asli akan mengalami perubahan. Salah satu sifat menurun adalah tipe golongan darah $\mathrm{ABO}$ yang ditentukan oleh alel ganda. Pemeriksaan tipe golongan darah dapat dilakukan dengan mudah, cepat dan murah. Oleh karena itu, tujuan penelitian ini adalah untuk mengetahui karakter genetik populasi warga bedeng 61B Desa Wonokarto, Kecamatan Sekampung, Kabupaten Lampung Timur, Lampung berdasarkan frekuensi alel dan genotip serta penyebaran alel sistem golongan darah $\mathrm{ABO}$.

\section{METODE}

Jenis penelitian ini adalah penelitian eksploratif yang digunakan untuk menelusuri kemungkinan adanya hubungan sebab akibat antara dua variabel yang belum pernah diketahui. Metode deskriptif digunakan untuk menggambarkan besarnya masalah (variabel orang, tempat, waktu) (Suparyanto, 2010).

Populasi pada penelitian ini adalah warga bedeng 61B Desa Wonokarto, Kecamatan Sekampung, Kabupaten Lampung Timur. Teknik pengambilan sampel yang digunakan adalah metode sensus yaitu semua anggota populasi yang memenuhi kriteria yang akan digunakan sebagai sampel. Data primer terdiri dari 2 (dua) jenis, yaitu data tipe golongan darah dan data kejadian evolutionary forces. Data tipe golongan darah diperoleh melalui pemeriksaan darah individu selaku responden secara langsung. Sedangkan data kejadian evolutionary forces dalam populasi diperoleh melalui pemberian kuesioner kepada masingmasing individu responden. Penelitian dilakukan di bedeng 61B Desa Wonokarto, Kecamatan Sekampung, Kabupaten Lampung Timur.

Analisis data genetika populasi dilakukan dengan menggunakan formula Hukum HardyWeinberg (Arisuryanti \& Daryono, 2007) sebagai berikut:

1. Frekuensi alel

$$
p+q+r=1
$$

2. Frekuensi genotip

$\mathrm{p}^{2}+2 \mathrm{pq}+\mathrm{q}^{2}+2 \mathrm{pr}+2 \mathrm{qr}+\mathrm{r}^{2}=1$

$$
\begin{aligned}
& \multicolumn{1}{l}{\text { Keterangan: }} \\
& \mathrm{p}= \text { frekuensi alel } \mathrm{A} \\
& \mathrm{q}= \text { frekuensi alel } \mathrm{B} \\
& \mathrm{r}= \text { frekuensi alel } \mathrm{O} \\
& \mathrm{p}^{2}= \text { frekuensi genotip tipe golongan } \\
& 2 \mathrm{pr}= \text { darah A homozigot } \\
& 2 \mathrm{pq}= \text { frekuensi genotip tipe golongan } \\
& \mathrm{q}^{2}= \text { darah A heterozigot } \\
& 2 \mathrm{qr}= \text { frekuensi genotip tipe golongan } \\
& \mathrm{r}^{2}= \text { darah AB } \\
& \text { frekuensi genotip tipe golongan } \\
& \text { darah B homozigot frekuensi } \\
& \text { genotip tipe golongan darah B } \\
& \text { heterozigot } \\
& \text { frekuensi genotip tipe golongan } \\
& \text { darah O }
\end{aligned}
$$

Sedangkan penyebaran frekuensi alel dilakukan dengan menggunakan rumus $\mathrm{Chi}$ square (Suryo, 2005), yaitu: 
Keterangan:

$$
\mathrm{X}^{2}=\sum\left(\mathrm{d}^{2} / \mathrm{e}\right)
$$

$\mathrm{d}=$ penyimpangan/deviasi yaitu selisih antara hasil yang diperoleh (o) dengan hasil yang diharapkan

$\mathrm{e}=$ hasil yang diharapkan

Analisis data kuesioner dilakukan secara deskriptif dengan distribusi frekuensi variabel untuk kategori dari masing-masing variabel yang diteliti. Analisis data variabel dilakukan dengan rumus sebagai berikut:

$\mathrm{P}=\frac{\sum f}{N} \times 100 \%$

Keterangan:

$\mathrm{P} \quad=$ Persentase

$\sum \mathrm{f} \quad=$ Jumlah frekuensi kategori

$\mathrm{N} \quad=$ Jumlah Total Kategori

\section{HASIL}

Tabel 1. Distribusi Responden Berdasarkan Tipe Golongan Darah

\begin{tabular}{cccc}
\hline No. & Tipe Golongan Darah & Jumlah Responden (orang/ jiwa) & Persentase \\
\hline 1 & A & 87 & 24,51 \\
\hline 2 & $\mathrm{~B}$ & 110 & 30,99 \\
\hline 3 & $\mathrm{AB}$ & 23 & 6,48 \\
\hline 4 & $\mathrm{O}$ & 135 & 38,03 \\
\hline & Total & 355 & 100 \\
\hline
\end{tabular}

Tabel 2. Distribusi Suku Bangsa Responden terhadap Tipe Golongan Darah

\begin{tabular}{clcccccc}
\hline \multirow{2}{*}{ No. } & \multirow{2}{*}{ Suku Bangsa } & \multicolumn{9}{c}{$\begin{array}{l}\text { Jumlah Responden dengan Tipe Golongan darah } \\
\text { (orang/ jiwa) }\end{array}$} & Total & $\%$ \\
\cline { 3 - 6 } & & $\mathrm{A}$ & $\mathrm{B}$ & $\mathrm{AB}$ & $\mathrm{O}$ & & \\
\hline 1. & Jawa & 79 & 93 & 23 & 123 & 318 & 89,58 \\
\hline 2. & Betawi & 1 & 0 & 0 & 2 & 3 & 0,85 \\
\hline 3. & Sunda & 1 & 1 & 0 & 3 & 5 & 1,41 \\
\hline 4. & Palembang & 0 & 1 & 0 & 0 & 1 & 0,28 \\
\hline 5. & Bengkulu & 0 & 0 & 0 & 1 & 1 & 0,28 \\
\hline 6. & Lampung & 6 & 15 & 0 & 6 & 27 & 7,61 \\
\hline & JUMLAH & & & & & 355 & 100 \\
\hline
\end{tabular}

Tabel 3. Distribusi Silsilah Wilayah Responden terhadap Tipe Golongan Darah

\begin{tabular}{|c|c|c|c|c|c|c|c|}
\hline \multirow[t]{2}{*}{ No. } & \multirow[t]{2}{*}{ Silsilah Wilayah } & \multicolumn{4}{|c|}{$\begin{array}{l}\text { Jumlah Responden dengan Tipe Golongan } \\
\text { darah (orang/ jiwa) }\end{array}$} & \multirow[t]{2}{*}{ Total } & \multirow[t]{2}{*}{$\%$} \\
\hline & & A & $\mathrm{B}$ & $\mathrm{AB}$ & $\mathrm{O}$ & & \\
\hline 1. & Bengkulu & 0 & 0 & 0 & 1 & 1 & 0,28 \\
\hline 2. & Palembang & 0 & 1 & 0 & 0 & 1 & 0,28 \\
\hline 3. & Lampung & 6 & 15 & 0 & 6 & 27 & 7,61 \\
\hline 4. & Jakarta & 1 & 0 & 0 & 2 & 3 & 0,85 \\
\hline 5. & Jawa Barat & 1 & 1 & 0 & 3 & 5 & 1,41 \\
\hline 6. & Jawa Tengah & 74 & 81 & 18 & 110 & 283 & 79,72 \\
\hline 7. & Yogyakarta & 0 & 4 & 3 & 2 & 9 & 2,54 \\
\hline \multirow[t]{2}{*}{8.} & Jawa Timur & 5 & 8 & 2 & 11 & 26 & 7,32 \\
\hline & \multicolumn{5}{|c|}{ JUMLAH } & 355 & 100 \\
\hline
\end{tabular}

Tabel 4. Distribusi Status Warga Responden terhadap Tipe Golongan Darah

\begin{tabular}{|c|c|c|c|c|c|c|c|}
\hline \multirow[t]{2}{*}{ No. } & \multirow[t]{2}{*}{ Silsilah Wilayah } & \multicolumn{4}{|c|}{$\begin{array}{c}\text { Jumlah Responden dengan Tipe Golongan } \\
\text { darah (orang/ jiwa) }\end{array}$} & \multirow[t]{2}{*}{ Total } & \multirow[t]{2}{*}{$\%$} \\
\hline & & A & $\mathrm{B}$ & $\mathrm{AB}$ & $\mathrm{O}$ & & \\
\hline 1. & Asli & 63 & 72 & 13 & 98 & 246 & 69,30 \\
\hline
\end{tabular}




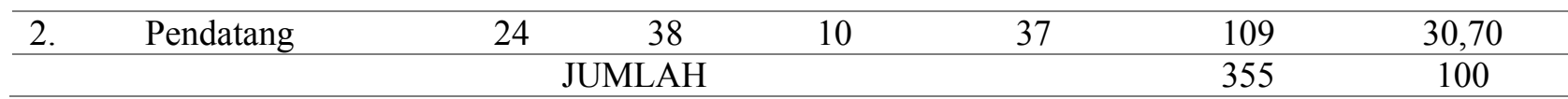

\section{Keterangan:}

Asli $=$ warga yang tinggal menetap dan lahir di Bedeng 61B

Pendatang = warga yang tinggal menetap di Bedeng 61B, namun tidak lahir di Bedeng 61B

Tabel 5. Data Alasan Kepindahan Pendatang

\begin{tabular}{clcccccc}
\hline \multirow{2}{*}{ No. } & \multirow{2}{*}{ Silsilah Wilayah } & \multicolumn{3}{c}{$\begin{array}{c}\text { Jumlah Responden dengan Tipe Golongan } \\
\text { darah (orang/ jiwa) }\end{array}$} & \multirow{2}{*}{ Total } & \multirow{2}{*}{$\%$} \\
\cline { 3 - 6 } & & $\mathrm{A}$ & $\mathrm{B}$ & $\mathrm{AB}$ & $\mathrm{O}$ & & 16 \\
\hline 1. & Pekerjaan & 5 & 4 & 0 & 7 & 16,68 \\
\hline 2. & Pendidikan & 0 & 0 & 0 & 0 & 0 & 0 \\
\hline 3. & Pernikahan & 9 & 21 & 5 & 14 & 49 & 44,95 \\
\hline 4. & Transmigrasi & 10 & 13 & 5 & 16 & 44 & 40,37 \\
\hline & & JUMLAH & & & 109 & 100 \\
\hline
\end{tabular}

Tabel 6. Uji Chi Square $\left(\mathrm{X}^{2}\right)$

\begin{tabular}{ccccc}
\hline $\begin{array}{c}\text { Fenotip } \\
\text { (Tipe Golongan Darah) }\end{array}$ & $\mathrm{o}$ & $\mathrm{e}$ & $\mathrm{d}$ & $\mathrm{X}^{2}$ \\
\hline $\mathrm{A}$ & 87 & 85,13 & 1,87 & 0,07 \\
\hline $\mathrm{B}$ & 110 & 108,10 & 1,90 & \\
\hline $\mathrm{AB}$ & 23 & 23,08 & $-0,08$ & \\
\hline O & 135 & 134,90 & 0,10 & \\
\hline JUMLAH & 355 & 355 & &
\end{tabular}

Keterangan:

$\mathrm{o}=$ hasil yang diobservasi

e $\quad=$ hasil yang diharapkan

$\mathrm{d}=\mathrm{o}-\mathrm{e}$

$\mathrm{X}^{2}=\sum(\mathrm{d} * \mathrm{~d} / \mathrm{e})$

Tabel 7. Frekuensi alel $\mathrm{I}^{\mathrm{A}}, \mathrm{I}^{\mathrm{B}}, \mathrm{I}^{\mathrm{O}}$ pada populasi warga Bedeng 61B Desa Wonokarto

\begin{tabular}{cc}
\hline Frekuensi Alel & Nilai \\
\hline $\mathrm{I}^{\mathrm{A}}$ & 0,17 \\
$\mathrm{I}^{\mathrm{B}}$ & 0,21 \\
$\mathrm{I}^{\mathrm{O}}$ & 0,62 \\
\hline
\end{tabular}

Tabel 8. Frekuensi genotip $\mathrm{I}^{\mathrm{A}} \mathrm{I}^{\mathrm{A}}, \mathrm{I}^{\mathrm{A}} \mathrm{I}^{\mathrm{O}}, \mathrm{I}^{\mathrm{B}} \mathrm{I}^{\mathrm{B}}, \mathrm{I}^{\mathrm{B}} \mathrm{I}^{\mathrm{O}}, \mathrm{I}^{\mathrm{A}} \mathrm{I}^{\mathrm{B}}, \mathrm{I}^{\mathrm{O}} \mathrm{I}^{\mathrm{O}}$ pada populasi warga Bedeng 61B Desa Wonokarto

\begin{tabular}{cc}
\hline Frekuensi Genotip & Nilai \\
\hline $\mathrm{I}^{\mathrm{A}} \mathrm{I}^{\mathrm{A}}$ & 0,0290 \\
$\mathrm{I}^{\mathrm{A}} \mathrm{I}^{\mathrm{O}}$ & 0,2108 \\
$\mathrm{I}^{\mathrm{B}} \mathrm{I}^{\mathrm{B}}$ & 0,0441 \\
$\mathrm{I}^{\mathrm{B}} \mathrm{I}^{\mathrm{O}}$ & 0,2604 \\
$\mathrm{I}^{\mathrm{A}} \mathrm{I}^{\mathrm{B}}$ & 0,0650 \\
$\mathrm{I}^{\mathrm{O}} \mathrm{I}^{\mathrm{O}}$ & 0,3800 \\
\hline
\end{tabular}

\section{PEMBAHASAN}

Frekuensi gen dan frekuensi genotip merupakan hal penting dalam melakukan karakterisasi suatu populasi. Berdasarkan frekuensi gen dan frekuensi genotip inilah kekhasan suatu populasi dapat diketahui

(Arisuryanti dkk., 2007). Frekuensi alel dan genotip dapat berubah oleh adanya evolutionary forces, antara lain mutasi, migrasi (gene flow), perkawinan tidak acak, genetic drift dan seleksi alam (Arisuryanti \& Daryono, 
2007). Hasil penelitian menunjukkan bahwa terdapat 2 (dua) jenis evolutionary forces yang berlangsung di populasi warga Bedeng 61B Desa Wonokarto, yaitu genetic drift dan gene flow.

Program kolonisasi oleh Pemerintah Belanda yang memindahkan sejumlah penduduk Pulau Jawa ke Lampung untuk membentuk populasi yang baru, menjadi salah faktor perubahan frekuensi alel dan genotip pada populasi yang baru. Kejadian ini dikategorikan sebagai efek pendiri (founder effect) yang merupakan salah satu dari genetic drift. Hal ini dibuktikan oleh data suku bangsa dan silsilah wilayah responden (Tabel 2 dan 3), dimana populasi Bedeng 61B didominasi oleh suku populasi pendiri yaitu suku jawa $(89,58 \%)$ dan silsilah wilayah populasi ini paling banyak berasal dari Jawa Tengah (79,72\%). Hal ini sesuai dengan data Witrianto (2010), yang menunjukkan secara nyata bahwa migrasi berlangsung oleh penduduk dari Jawa Tengah menuju Lampung sebanyak 815 jiwa dan 77 jiwa pada periode yang berbeda. Hadirnya pendatang dalam populasi Bedeng 61B menyebabkan terjadinya aliran gen (gene flow), jumlah pendatang adalah 109 orang $(30,7 \%)$ (Tabel 4). Setelah diketahui bahwa evolutionary forces terjadi pada populasi secara nyata, maka dilakukan penghitungan frekuensi alel dan genotip pada populasi tersebut, maka dapat diketahui perubahan frekuensi tersebut menyimpang atau tidak terhadap Hukum Kesetimbangan Hardy Weinberg.

Total jumlah gen pada genom manusia berkisar antara $70.000-80.000$ (Strachan \& Read, 1999). Salah satunya adalah gen penyandi golongan darah. Land Steiner dalam Suryo (2005) mengemukakan bahwa golongan darah Sistem ABO dapat diwariskan dan dibedakan menjadi empat golongan yaitu A, B, $\mathrm{AB}$ dan $\mathrm{O}$.

Di Indonesia, dan Surabaya pada khususnya, urutan jumlah golongan darah terbanyak berturut-turut adalah golongan darah $\mathrm{O}$, golongan darah $\mathrm{B}$, golongan darah $\mathrm{A}$, dan golongan darah AB (Pratiwi \& Perdanakusuma, 2008). Hal ini sesuai dengan hasil penelitian (Tabel 1), dimana jumlah responden yang memiliki tipe golongan darah $\mathrm{A}, \mathrm{B}, \mathrm{AB}$ dan $\mathrm{O}$ adalah berturut-turut sebanyak 87 orang $(24,51 \%), 110$ orang $(30,99 \%), 23$ orang $(6,48 \%)$ dan 135 orang $(38,03 \%)$. Namun, nilai persentase tersebut berbeda dengan hasil penelitian Darmawati dkk (2005), dimana persentase tertinggi didapati pada warga bergolongan darah B yaitu 59 orang $(48,76 \%)$. Hasil juga tidak sesuai dengan pendapat Suryo (1997) yang menyatakan bahwa golongan darah orang Indonesia pada umumnya adalah B. Kejadian demikian dapat terjadi, karena setiap populasi memiliki karakter susunan genetik dan persebaran alelalel yang bervariasi. Land Steiner dalam Suryo (2005) mengemukakan bahwa golongan darah Sistem ABO ditentukan oleh suatu seri alel ganda antara lain $\mathrm{I}^{\mathrm{A}}, \mathrm{I}^{\mathrm{B}}$, dan $\mathrm{I}^{\mathrm{O}}$, dimana hampir seluruh populasi penduduk di dunia memiliki ketiga alel tersebut, walaupun persebaran alelnya berbeda-beda.

Karakter susunan genetik dan persebaran alel-alel yang bervariasi, sangat ditentukan oleh gen parentalnya (Sinnot (1958) dalam Darmawati dkk., 2005). Gen parental pada anggota populasi pendiri Bedeng 61B memiliki ketiga alel pada seri alel ganda sistem golongan darah $\mathrm{ABO}$, antara lain $\mathrm{I}^{\mathrm{A}}, \mathrm{I}^{\mathrm{B}}$, dan $\mathrm{I}^{\mathrm{O}}$. Tabel 5 (lima) menunjukkan distribusi tipe golongan darah warga transmigran yang merupakan populasi pendiri Bedeng 61B, berturut-turut, yaitu tipe golongan darah $\mathrm{A}, \mathrm{B}$, $\mathrm{AB}$ dan $\mathrm{O}$ sebanyak 10 orang $(22,73 \%), 13$ orang $(29,55 \%), 5$ orang $(11,36 \%)$ dan 16 orang $(36,36 \%)$. Persebaran tipe golongan darah populasi pendiri sesuai dengan persebaran populasi saat ini.

Frekuensi alel golongan darah Sistem ABO pada populasi warga Bedeng 61B Desa Wonokarto dapat dilihat pada tabel 7 (tujuh). Alel $\mathrm{I}^{\mathrm{O}}$ memiliki nilai tertinggi dalam populasi, hal ini menunjukkan bahwa kejadian kawin acak yang terjadi pada populasi tersebut lebih banyak dilakukan oleh warga bergolongan darah A dan B dengan genotip heterozigot. Hal ini sesuai dengan data pada tabel 8 yang menunjukkan bahwa frekuensi genotip $\mathrm{I}^{\mathrm{A}} \mathrm{I}^{\mathrm{O}}$ dan $\mathrm{I}^{\mathrm{B}} \mathrm{I}^{\mathrm{O}}$ yang tinggi.

Genotip golongan darah A dan B yang homozigot memiliki nilai yang rendah dalam 
populasi, berturut-turut yaitu 0,0290 dan 0,0441 (Tabel 8). Nilai tersebut menunjukkan bahwa dalam populasi warga Bedeng 61B Desa Wonokarto hanya didapatkan 11 orang yang bergenotip golongan darah A homozigot dan 16 orang dengan genotip golongan darah B homozigot.

Perubahan frekuensi alel dan genotip suatu populasi merupakan indikasi adanya mikroevolusi, yaitu evolusi yang terjadi pada tingkat kecil (gen). Campbell et al., (2003) menyatakan bahwa apabila frekuensi alel atau genotip menyimpang dari nilai yang diharapkan dari kesetimbangan HardyWeinberg, maka populasi itu dikatakan sedang berevolusi. Uji Chi-Square $\left(\mathrm{X}^{2}\right)$ merupakan uji yang dapat menunjukkan adanya penyimpangan struktur genetik terhadap Hukum Hardy-Weinberg. Hasil uji Chi-Square data golongan darah populasi warga Bedeng 61B Desa Wonokarto, diperoleh nilai $\mathrm{X}^{2}$ sebesar 0,07 (Tabel 6), dan critical value pada $\alpha 5 \%$ adalah 7,815 (untuk $d F=3$ ). Oleh karena nilai $\mathrm{X}^{2}<$ critical value, maka populasi warga Bedeng 61B berada dalam kesetimbangan Hukum Hardy-Weinberg. Dua bentuk evolutionary forces yang berlangsung pada populasi tersebut tidak memiliki pengaruh besar untuk dapat menyebabkan penyimpangan terhadap Hukum Kesetimbangan Hardy-Weinberg.

\section{UCAPAN TERIMA KASIH}

Kegiatan penelitian ini telah mendapatkan banyak masukan dan bantuan dari berbagai pihak, terutama Kepala, Sekretaris dan Ketua Rukun Tangga, serta warga Desa Wonokarto Kabupaten Lampung Timur. Ucapan terima kasih dan penghargaan yang sebesar-besarnya, peneliti sampaikan kepada segenap pihak yang telah berkontribusi dalam kelancaran pelaksanaan penelitian ini.

\section{DAFTAR PUSTAKA}

Arisuryanti T dan Daryono BS. 2007. Genetika Populasi. Yogyakarta: Fakultas Biologi Universitas Gadjah Mada.

Arisuryanti T, Handayani NSN. dan Daryono, BS. 2007. Genetika. Yogyakarta: Fakultas Biologi UGM.

Campbell R dan Mitchell. 2003. Biologi Jilid 2. Jakarta: Erlangga.

Darmawati, Suryawati E dan Suhendri E. 2005. Frekuensi dan Penyebaran Alel Golongan Darah A B O Siswa SMUN 1 Suku Bangsa Melayu di Kecamatan Rupat Kabupaten Bengkalis Riau. Jurnal Biogenesis. vol. 1 (2): 66-69.

Pratiwi KD dan Perdanakusuma D. 2008. Hubungan Antara Golongan Darah Dengan Timbulnya Keloid Pascaluka. [Karya Ilmiah]. Surabaya: Departemen / SMF Ilmu Bedah Plastik Fakultas Kedokteran Universitas Airlangga, RSUD Dr. Soetomo Surabaya.

Suparyanto. 2010. Metodologi Penelitian Kesehatan. Jakarta: Rineka Cipta

Suryo. 1997. Genetik Manusia. Yogyakarta: Universitas Gadjah Mada Press.

Suryo. 2005. Genetika. Yogyakarta: Universitas Gadjah Mada Press.

Setiawan D. 2009. Kampung Halamanku. http://www.danisetiawanku.com. Diakses 24 Februari 2014.

Sofro ASM. 1994. Keanekaragaman Genetik. Yogyakarta: Penerbit Andi Offset.

Strachan T and Read A. 1999. Human Molecular Genetics. $2^{\text {nd }}$ edition. Chapter 7: Organization of the human genome. New York: Garland Science. http://www.ncbi.nlm.nih.gov. Diakses 15 Juli 2014.

Witrianto. 2010. Transmigrasi di Indonesia. http://witrianto.blogdetik.com. Diakses 24 Februari 2014. 